\title{
Digestibility and Physicochemical Characteristics of Tambaqui Waste Biological Silage Meal Included in Commercial Layer Diets*
}

\section{-Author(s)}

Guimarães CC' (iD https://orcid.org/0000-0003-1970-3403 Silva AJl" (iD https://orcid.org/0000-0001-8663-2786 Cruz FGGIII (iD https://orcid.org/0000-0001-9076-9849 Rufino JPF' (iD) https://orcid.org/0000-0002-1605-5255 Silva AF' (D) https://orcid.org/0000-0003-3343-9530 Costa VR' (iD https://orcid.org/0000-0002-0904-2376

Graduate Program in Animal Science, College of Agrarian Sciences, Federal University of Amazonas, Manaus, Amazonas, Brazil.

Department of Fishery Sciences, College of Agrarian Sciences, Federal University of Amazonas, Manaus, Amazonas, Brazil.

III Department of Animal and Vegetable Production, College of Agrarian Sciences, Federal University of Amazonas, Manaus, Amazonas, Brazil.

* Part of M.Sc. degree dissertation of the first author.

\section{ABSTRACT}

This study aimed at evaluating the effects of the physicochemical and nutritional characteristics of a biological silage meal made of tambaqui waste on dietary nutrient apparent digestibility and energy metabolism of commercial layer diets. Seventy-two 61-week-old Hisex White hens were assigned according to a completely randomized experimental design in two treatments: control diet and diet with $5 \%$ tambaqui waste biological silage meal (TWBSM), with six replicates of six birds each. The ensiled biomass presented grey brown color, acid aroma, viscous texture, $5.27 \pm 0.016 \mathrm{pH}, 96.28 \%$ dry matter (DM), $33.29 \%$ crude protein (CP), 33.65\% ether extract (EE), $14.37 \%$ ashes,

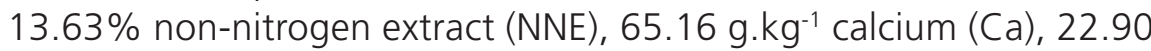
g. $\mathrm{kg}^{-1}$ phosphorus (P), and 5,666.07 kcal. $\mathrm{kg}^{-1}$ gross energy (GE). Higher ( $p>0.05$ ) coefficients of apparent digestibility of DM, crude fiber, EE, and ash, and higher coefficient of GE metabolizability were obtained in the diet with 5\% TWBSM. Due to its high CP content $(33.29 \%$ on DM basis), TWBSM may be considered a protein feedstuff. Although no differences in CP digestibility $(p>0.05)$ were detected, TWBSM presented high CP digestibility than the control diet due to proteins hydrolysis as a result of lactic fermentation by microorganisms during the ensilage process, yielding autolysed proteins of high biological value. Our results indicate that the biological silage meal produced from the residual biomass of tambaqui can be included up to $5 \%$ in commercial layer diets as it has good nutrient digestibility, and therefore, may potentially be used as a dietary energy and protein source.

\section{INTRODUCTION}

Poultry egg and meat production is an important economic activity worldwide. However, one of the obstacles of this industry in some Brazilian regions is the lack of availability of corn and soybean, which are the main feedstuffs of poultry diets, consequently increasing production costs (Batalha et al., 2018).

Studies on alternative feed ingredients have shown their potential inclusion or replacement of conventional feedstuffs in poultry diets in order to reduce feeding costs, which represent $70 \%$ of the total production cost (Cruz et al., 2016). The inclusion of by-products in poultry diets requires lower investments because of their lower cost, while supplying high nutritional levels (Enke et al., 2010).In this context, fish by-product silage has significant economic advantages, as their production requires simple technology, independently of the production scale (Hisano et al., 2012), as well as allows the low-cost transformation of waste materials into high nutritional quality feedstuffs and minimizes environmental pollution (Batalha et al., 2018). 
Based on this perspective, the objective of using fish by-product silage as an alternative ingredient is to enhance productivity and profitability and should not negatively affect animal performance and physiology. This requires a clear understanding of its protein and mineral contents, energy level, as well as nutrient availability and utilization by the birds (Oliveira et al., 2012).

In view of the above, this study aimed at determining the chemical and nutritional composition of tambaqui (Colossomamacropomum Cuvier, 1818) waste biological silage meal and the effects of its dietary inclusion in commercial layer diets on nutrient apparent digestibility and energy metabolism.

\section{MATERIAL AND METHODS}

The experiment was conducted at the Fish Technology Laboratory, College of Agrarian Sciences (FCA), Federal University of Amazonas (UFAM), Manaus, State of Amazonas, Brazil, where the procedures for obtaining biological silage made of tambaqui (Colossomamacropomum Cuvier, 1818) waste were developed, and its physical and chemical composition was determined; and at the Poultry Sector, located in the same facilities, where the digestibility assay was performed.

The experimental procedures were approved by the Committee for the Ethical Use of Animals (CEUA - protocol n. 053/2017) of the Federal University of Amazonas, Manaus, AM, Brazil.

The tambaqui by-product silage was prepared with viscera, fins, few scales, and gills discarded from the processing of tambaqui-curumim (fish weighing 500 to $800 \mathrm{~g}$ ). The material was obtained in June 2017 from a commercial fish processing plant located in Manaus, and was transported in a thermal box ( $50 \mathrm{~L})$ to the laboratory.

The residues were ground (5-mm mesh), weighed, and $5 \mathrm{~kg}$ of the ground mass was placed in individual 12-L plastic buckets. The following materials were added to each bucket: $2.5 \%$ (volume/weight) of inoculum (pure cultures of the bacterium Lactobacillus plantarum as proteolytic microorganisms), $7.5 \%$ (weight/weight) of shredded manioc (Manihot esculenta Crantz) as a carbohydrate source; $0.1 \%$ (weight/weight) of benzoic acid as fungicidal and bactericidal preservative, and $0.1 \%$ (weight/weight) ascorbic acid as antioxidant, according to the method proposed by Vidotti et al. (2002).The material was thoroughly homogenized, after which the buckets were hermetically sealed in order to provide anaerobic conditions. Buckets were stored at room temperature $\left(32.5^{\circ} \mathrm{C}\right)$ for 14 days.

Every three days, mass hydrogen ionic potential $(\mathrm{pH})$ was measured using a bench $\mathrm{pH}$ meter, and titratable acidity by titration of $0.1 \mathrm{~N} \mathrm{NaOH}$, using $0.5 \mathrm{~mL}$ of phenolphthalein $(1.5 \%)$ as indicator. The changes in the product were accompanied by observations of the organoleptic characteristics color, aroma, and texture.

After 14 days, the silage was dried in a forcedventilation oven for 72 hours at $65 \pm 2^{\circ} \mathrm{C}$. At the end of the drying period, the total yield of the dry product was $20 \%$ relative to the fresh ensiled mass, and ground to obtain the biological silage meal made of tambaqui waste.

The chemical composition (dry matter, crude protein, ether extract, ashes, non-nitrogenous extract and crude fiber) of the fresh waste and biological silage were determined according to methods proposed by Silva and Queiroz (2012). Both products were digested in nitricperchloric acid and the mineral contents were quantified by atomic absorption spectrophotometer (calcium - Ca) and by colorimetry (phosphorus - P) in a spectrophotometer, using ammonium molybdate and ascorbic acid, according to the methodology described by Sarruge \& Haag (1974) at the Laboratory of Soils and Plants of EMBRAPA Amazônia Ocidental, Brazil.

The diets (Table 1) were formulated using the software Supercrac (2004) to meet the layers' nutritional requirements and according to the feedstuff values of the Brazilian Tables for Poultry and Swine (Rostagno et al., 2011), except for the chemical composition of tambaqui waste silage. Seventy-two, 62-week-old Hisex White hens were housed in 12 cages $(1.0-\mathrm{m}$ long, 0.45-deep, 0.45-m high), with 0.50-m internal lengthwise divisions.

Birds were weighed to standardize the plots, presenting an average weight of $1.41 \pm 0.0656 \mathrm{~kg}$, and distributed according to a completely randomized experimental design into two treatments with six replicates of six birds each. The treatments consisted of a control diet (based on corn and soybean meal) and an experimental diet with $5 \%$ inclusion of tambaqui waste biological silage meal (TWBSM). The experimental period lasted for 12 days, considering seven days for adaptation of birds to the diets and facilities and another five days for excreta collection and data recording, according to methodology proposed by Rodrigues et al. (2005) and Sakomura \& Rostagno (2007). 
Table 1 - Feedstuffs and nutritional composition of the experimental diets containing no or $0.5 \%$ tambaqui waste biological silage meal (TWBSM).

\begin{tabular}{|c|c|c|}
\hline \multirow{2}{*}{ Ingredients } & \multicolumn{2}{|c|}{$\begin{array}{c}\text { Tambaqui waste biological silage meal } \\
\text { levels }\end{array}$} \\
\hline & $0.0 \%$ & $0.5 \%$ \\
\hline Corn $(7.88 \%)$ & 62.2936 & 61.4253 \\
\hline Soybean meal (46\%) & 25.8320 & 22.6211 \\
\hline BSMTW & - & 5.0000 \\
\hline Limestone & 9.2395 & 8.3504 \\
\hline Dicalcium phosphate & 1.6929 & 1.7289 \\
\hline Vit. min. supplement ${ }^{1}$ & 0.5000 & 0.5000 \\
\hline DL-methionine (99\%) & 0.0921 & 0.0243 \\
\hline Salt & 0.3500 & 0.3500 \\
\hline Total & 100.00 & 100.00 \\
\hline Nutrient & Nutritional levels & \\
\hline $\begin{array}{l}\text { Metabolizable energy, } \text { kcal- } 1 /^{-1} \\
\text { kg }\end{array}$ & $2,747.51$ & $2,746.74$ \\
\hline Crude protein, \% & 17.000 & 17.000 \\
\hline Methionine + Cystine, \% & 0.6272 & 0.6277 \\
\hline Methionine, \% & 0.3600 & 0.3600 \\
\hline Calcium, \% & 4.0000 & 4.0000 \\
\hline Available phosphorus, \% & 0.4000 & 0.4000 \\
\hline Sodium, \% & 0.1560 & 0.1560 \\
\hline
\end{tabular}

${ }^{1}$ Guaranteedlevels per kilogramoftheproduct: Vitamin A 2,000,000 IU, Vitamin D3 400,000 IU, Vitamin E 2,400 mg, Vitamin K3 400 mg, Vitamin B1 100 mg, Vitamin B2 760 mg, Vitamin B6 100 mg, Vitamin B12 2,400 mcg, Niacin 5,000 mg, Calcium Pantothenate 2,000 mg, Folicacid 50 mg, Coccidiostat 12,000 mg, Choline 50,000 mg, Copper 1,200 mg, Iron 6,000 mg, Manganese 14,000 mg, Zinc 10,000 mg, lodine 100 mg. Selenium 40 mg. Vehicle q.s.p. 1,000 g.

Dietary nutrient digestibility was determined using the total excreta collection method. For this procedure, a plastic-lined tray was placed under each cage, from which the excreta were collected twice daily at 8:00 hand at 16:00 h. The collected excreta were placed in plastic bags duly identified according to the treatment, sealed, and stored in a refrigerator.

At the end of the excreta collection period, samples were thawed at room temperature, homogenized per experimental unit, driedin a forced-ventilation oven at $55^{\circ} \mathrm{C}$ for $72 \mathrm{~h}$, and then ground.

Both the experimental diets and the excreta samples were analyzed for dry matter, crude protein, ether extract, crude fiber, and ash contents, according to the techniques described by Silva \& Queiroz (2012).

Based on the analysis results, the coefficients of nutrient digestibility (\%), metabolizable energy values ( $\left.\mathrm{kcal} . \mathrm{kg}^{-1}\right)$, and the coefficients of apparent metabolizability of gross energy of the diets (\%) were calculated according to the equations described by Matterson et al. (1965) for poultry feed evaluation (Sakomura \& Rostagno, 2007).

Statistical analysis was performed using the software Statistical Analysis System (SAS, 2008) and treatment means were compared by Tukey's test at 5\% significance level.

\section{RESULTS AND DISCUSSION}

The $\mathrm{pH}$ and titratable acidity of the tambaqui biological silage was monitored over 72 -h periods for 14 days and the results are presented in Table 2 . Initial $\mathrm{pH}$ and titratable acidity were $5.95 \pm 0.06$ and $3.11 \pm 0.10 \%$, respectively. The increasing acidity observed during the first $72 \mathrm{~h}$ is consistent with that verified by Jatobá \& Oliveira Filho (2017).

Table 2 - Values of $\mathrm{pH}$ and titratable acidity during the inoculation of biological silage meal of tambaqui waste*.

\begin{tabular}{lcc}
\hline Days of inoculation & $\mathrm{pH}$ & Titratable acidity $(\%)$ \\
\hline 0 (start) & $5.95 \pm 0.06$ & $3.11 \pm 0.10$ \\
3 & $4.58 \pm 0.05$ & $3.98 \pm 0.05$ \\
7 & $4.57 \pm 0.06$ & $3.90 \pm 0.05$ \\
10 & $5.16 \pm 0.36$ & $4.08 \pm 0.25$ \\
14 & $5.27 \pm 0.16$ & $3.87 \pm 0.04$ \\
\hline
\end{tabular}

*Mean \pm standard deviation of three replicates.

This fast $\mathrm{pH}$ reduction during the first 72 hours indicates fermentation by the added homofermentative lactic acid producing bacteria, which was accelerated by the carbohydrates available in the medium. Silva (2015) reports that fermentative processes that occur in the medium reduce the $\mathrm{pH}$ from 4.5 to 4.0 in 48 to 50 hours of inoculation.

On day 14 after the mass was ensiled, the medium remained acidic, with $5.27 \pm 0.16$ final $\mathrm{pH}$ and $3.87 \pm 0.04$ final titratable acidity, in agreement with the values reported by Nascimento et al. (2014) in fishwaste biological silage at $13^{\circ} \mathrm{C}$ on day 18 .

Changes in the organoleptic characteristics of the ensiled mass that may have compromised its quality were not observed. According Honorato et al. (2011), the quality of biological silages is directly associated with the production of lactic acid in the medium by lactic-acid bacteria. According Nascimento et al. (2014), the fast $\mathrm{pH}$ decrease of the fish-waste mass during the first hours of ensilage is essential to prevent the growth of pathogenic bacteria, such as Clostridium botulinum, and the production of toxins. The replication of coliforms, Staphylococcusaureus, and Salmonella spp. are restricted by acid $\mathrm{pH}$, anaerobiosis, and by the presence of some antibacterial substances produced by lactic-acid bacteria, which are also responsible for the production of odor of fish-waste silage (Maia Junior \& Salles, 2013).

During the biological process of silage production, there were evident organoleptic changes of the 
ensiled mass, especially in the color and odor. The liquefaction observed in the initial 72 hours modified the mass texture, turning it into a homogenous paste. In addition, color changes were observed already on the first day: from dark pink on d1 to grey brown on d7 until the end of the process.

Ramirez et al. (2013) also reported that the use of viscera in the fish waste silage accelerates the proteolytic process, and that it is independent of the production of lactic acid; however, the inclusion of lactic-acid bacteria preserves the quality of the ensiled material by producing its own lactic acid.

The chemical composition of the biological silage (Table 3) was significantly different differences $(p<0.05)$ from that of the fresh waste of tambaqui. It was observed that the ensiling process considerably improved the availability of nutrients in the final product compared with the fresh waste, as observed by the values calculated on dry matter basis.

Table 3 - Chemical composition of the evaluated fresh tambaqui waste and of the biological silage meal.

\begin{tabular}{lcccc}
\hline Chemical composition & Fresh waste* & $\begin{array}{c}\text { Biological } \\
\text { silage }\end{array}$ & $p$-value & CV(\%) \\
\hline Dry matter, \% & $24.33 \pm 0.66^{\mathrm{b}}$ & $96.28 \pm 0.13^{\mathrm{a}}$ & $0.01^{*}$ & 3.65 \\
\hline Crude protein, \% & $7.08 \pm 0.25^{\mathrm{b}}$ & $33.29 \pm 1.63^{\mathrm{a}}$ & $0.01^{*}$ & 4.85 \\
\hline Ether extract, \% & $8.83 \pm 0.05^{\mathrm{b}}$ & $33.65 \pm 0.31^{\mathrm{a}}$ & $0.01^{*}$ & 3.98 \\
\hline Ashes, \% & $3.81 \pm 0.14^{\mathrm{b}}$ & $14.37 \pm 0.51^{\mathrm{a}}$ & $0.01^{*}$ & 7.85 \\
Non-nitrogenous extract, \% & $3.70 \pm 0.38^{\mathrm{b}}$ & $13.63 \pm 1.82^{\mathrm{a}}$ & $0.01^{*}$ & 9.54 \\
\hline Crude fiber, \% & $0.90 \pm 0.29^{\mathrm{b}}$ & $1.36 \pm 0.91^{\mathrm{a}}$ & $0.05^{*}$ & 8,56 \\
Calcium, g.kg-1 & $23.09^{\mathrm{a}}$ & $21.26^{\mathrm{b}}$ & $0.05^{*}$ & 4.58 \\
\hline Phosphorus, g.kg-1 & $13.23^{\mathrm{a}}$ & $11.98^{\mathrm{b}}$ & $0.05^{*}$ & 3.96 \\
\hline Gross energy, kcal.kg-1 & $1,420.94^{\mathrm{b}}$ & $5,666.07^{\mathrm{a}}$ & $0.01^{*}$ & 4.56 \\
\hline
\end{tabular}

${ }^{*}$ All nutrient values were calculated on dry matter basis.

$\mathrm{CV}$ - Coefficient of variation; *Means followed by different lowercase letters in the same row are significantly different by Tukey's test $5 \%$ significance $(p<0.05)$.

According to Vidotti et al. (2002), fish waste source and processing method, including fish species, head size, production system, body fat content, etc.) greatly influence the chemical composition of the final product. In the present study, only the waste of tambaqui processing (viscera, fins, few scales, and gills) was used. Large tambaqui have high meat yield, but accumulate high volumes on non-edible fat in the viscera (Kubitza, 2004). The waste ensiled in the present study derived from tambaqui weighing 500 to $800 \mathrm{~g}$, which present low fat accumulation in the abdominal cavity, in addition of lower viscera yield and higher fillet yield compared with larger fish (Lima et al., 2018), consequently providing higher levels of protein, soluble carbohydrates (non-nitrogenous extract), insoluble carbohydrates (fibers) and gross energy.
The obtained crude protein content of the evaluated tambaqui biological silage (33.29\%) was close that that reported by Honorato et al. (2012), of $33.62 \%$, in tilapia fillet waste silage and lower than that observed by Cândido et al., (2016), of 39.01\%, in the silage of tilapia mortality during production.

The high ash content observed may be attributed to the presence of fins, few scales and gills in the tambaqui waste. The obtained calcium (Ca) and phosphorus ( $\mathrm{P}$ ) levels are lower than those found by Batalha et al. (2017) in pirarucu waste acid silage. According Sankar et al. (2008), fish scales are composed of connective tissue proteins, collagen, and covered with calcium salts and other minerals, which increase the ash content of fish waste.

The calculated coefficients of apparent digestibility (CAD) of the dietary nutrients are presented in Table 4. The CAD of dry matter, crude fiber, and ether extract were significantly different $(p<0.05)$ between the control diet and that containing 5\% TWBSM, indicating that the layers fed the diet with 5\% biological silage meal showed better nutrient utilization than those fed the control diet. These results may be attributed to the higher nutrient content of TWBSW compared with that of the conventional control diet.

Table 4 - Coefficients of apparent digestibility (CAD)of the nutrients in the control diet and in the experimental diet containing $5 \%$ of biological silage meal of tambaqui waste (TWBSM) fed to commercial layers.

\begin{tabular}{|c|c|c|c|c|}
\hline \multirow{2}{*}{ CAD (\%) } & \multicolumn{2}{|c|}{ Experimentaldiets } & \multirow[t]{2}{*}{$p$-value } & \multirow[t]{2}{*}{$\mathrm{CV}(\%)$} \\
\hline & Control & $5 \%$ TWBSM & & \\
\hline Dry matter & $78.94^{b}$ & $81.41^{\mathrm{a}}$ & $0.02^{*}$ & 2.95 \\
\hline Crude protein & 51.91 & 51.10 & $0.70^{\text {ns }}$ & 4.71 \\
\hline Crude fiber & $25.38^{\mathrm{b}}$ & $30.09^{a}$ & $0.04^{*}$ & 10.01 \\
\hline Non-nitrogenous extract & 86.16 & 85.58 & $0.25^{\text {ns }}$ & 4.25 \\
\hline Ether extract & $67.59^{b}$ & $74.36^{a}$ & $0.02 *$ & 3.51 \\
\hline Ashes & 75.29 & 75.28 & $0.29^{\text {ns }}$ & 2.63 \\
\hline
\end{tabular}

CV - Coefficient of variation; * Means followed by different lowercase letters in the same row are significantly different by Tukey's test at $5 \%$ significance level $(p<0.05)$. ns - not significant.

Tambaqui waste biological silage meal can be considered a protein source (33.29\% on DM basis). Despite not being significantly different from that of fresh waste $(p>0.05)$, the coefficient of crude protein of TWBSM is high, which are possibly due to protein hydrolyzation by microorganisms through lactic fermentation during the ensilage process, resulting in a product that is a source of autolysed proteins of high biological value. According Ramírez-Ramírez et al. (2008), feeding monogastric animals with diets which protein includes a pre-digested portion favors 
protein digestibility. Consequently, the availability of free amino acids and small peptides that can be easily absorbed may enhance protein deposition in animals that most depend on the protein content of exogenous diets (Honorato et al., 2011).

In the present experiment, the layers fed the diet with 5\% TWBSM showed better dietary fat utilization than those fed the control diet, as demonstrated by their higher ether extract $C A D(P<0.05)$. This result may be attributed to the high ether extract content in this feedstuff (33.65\%). Yamamoto et al. (2007) reported that freshwater fish silage has high fat content and digestibility due to its lipid composition, allowing its easy absorption by sheep. Several studies (Widjastuti et al., 2011; Rahman and Koh, 2016; Batalha et al., 2017) reported that the inclusion of fish silage in poultry diets provided high dietary nutrient digestibility.

The dietary apparent metabolizable energy (AME) contents and the coefficients of apparent energy metabolizability (CAEM) are presented in Table 5 . Although no AME content differences $(p>0.05)$ were detected between the control and the 5\% PWBSM diets, the higher CAEM $(p<0.05)$ obtained in the layers fed 5\% PWBSM compared to those fed the control diet indicates better utilization of dietary energy.

Table 5 - Apparent metabolizable energy (AME) content and coefficient of apparent energy metabolizability (CAEM) of the control diet and of the diet containing $5 \%$ of tambaqui waste biological silage meal fed to commercial layers.

\begin{tabular}{|c|c|c|c|c|}
\hline & \multicolumn{2}{|c|}{ Experimental diets } & \multirow[t]{2}{*}{$p$-value } & \multirow{2}{*}{$\begin{array}{l}\mathrm{CV} \\
(\%)\end{array}$} \\
\hline & Control & $5 \%$ TWBSM & & \\
\hline AME $\left(\mathrm{kcal} \mathrm{kg}^{-1}\right)$ & $3,266.53$ & $3,283.58$ & $0.65^{\text {ns }}$ & 1.32 \\
\hline CAEM (\%) & $80.76^{b}$ & $82.73^{a}$ & $0.01 *$ & 1.33 \\
\hline
\end{tabular}

$\mathrm{CV}$ - Coefficient of variation; *Means followed by different lowercase letters in the same row are significantly different by Tukey's test at $5 \%$ significance $(p<0.05)$; ns not significant.

Oliveira et al. (2014) determined ME ranging from $3,804 \mathrm{kcal} . \mathrm{kg}^{-1}$ to $3,842 \mathrm{kcal} . \mathrm{kg}^{-1}$ in broilers diets including $40 \%$ fish waste meal ensiled with different carbohydrates sources.

The results of the present experiment showed that the diet containing tambaqui waste biological silage meal had high AME content and gross energy metabolizability. In pigs, Cândido et al. (2016) observed high ME value $\left(4,032.09 \mathrm{kcal}^{\mathrm{kg}}{ }^{-1}\right)$ when fish silage meal was included in the feed. However, the ME value differences among studies are related to variations in the chemical composition of feeds rather than to animal physiology differences (Calderano et al., 2010).

\section{CONCLUSIONS}

Our results indicate that the biological silage meal produced from the residual biomass of tambaqui can be included up to $5 \%$ in commercial layer diets as it has good nutrient digestibility, and therefore, may potentially be used as a dietary energy and protein source.

\section{REFERENCES}

Batalha OS, Alfaia SS, Cruz FGG, Jesus RS, Rufino JPF, Costa VR. Digestibility and physico-chemical characteristics of acid silage meal made of pirarucu waste in diets for commercial laying hens. Acta Scientiarum. Animal Sciences 2017;39(3):251-257

Batalha OS, Alfaia SS, Cruz FGG, Jesus RS, Rufino JPF, Silva AF. Pirarucu by-product acid silage meal in diets for commercial laying hens. Revista Brasileira de Ciência Avícola 2018;20(2):371-376.

Calderano AA, Gomes PC, Albino LFT, Rostagno HS, Souza RM, Mello HHC. Composição química e energética de alimentos de origem vegetal determinada em aves de diferentes idades. Revista Brasileira de Zootecnia 2010;39(2):320-326.

Cândido RS, Watanabe PH, Moreira LL, Kubota GA, Rodrigues BBV, et. Digestibilidade da silagem de pescado com inóculo microbiológico para suínos na fase de crescimento. Anais do $25^{\circ}$ Congresso Brasileiro de Zootecnia; 2016; Fortaleza, Ceará. Brasil. p. 27-29.

Cruz FGG, Rufino JPF, Melo RD, Feijó JC, Damasceno JL, Costa APGC. Perfil socioeconômico da avicultura no setor primário do estado do Amazonas, Brasil. Revista em Agronegócios e Meio Ambiente 2016;9(2):371-391.

Enke DBS, Tabeleão V, Rocha CB, Rutz F, Soares LAS. Efeito da inclusão de farinha de silagem de pescado adicionada de farelo de arroz desengordurado na dieta de codornas japonesas (Coturnix coturnix japonica). Revista Brasileira de Higiene e Sanidade Animal 2010;4(2):114.

Hisano $\mathrm{H}$, Ishikawa MM, Portz L. Produção de silagem ácida a partir de vísceras de surubim (Pseudoplatystoma sp.) e avaliação da digestibilidade para tilápia-do-nilo. Revista Brasileira de Saúde e Produção Animal 2012;13(3):872-879.

Honorato CA, Frizzas OG, Carneiro DJ. Digestibilidade da silagem de peixe com diferentes tempos de armazenamento para alimentação do pacu (Piaractus mesopotamicus). Ensaios e Ciência:Ciências Biológicas, Agrárias e da Saúde 2012;16(5):85-95.

Honorato CA, Stech MR, Carneiro DJ. Silagem biológica de resíduos de peixe em dietas para alevinos de tilápia do Nilo. Revista Acadêmica: Ciência Animal 2011;9(4):371-377.

Jatobá RF, Oliveira Filho PRC. Silagem biológica elaborada com resíduos de filetagem de saramunete (Pseudupeneusmaculatus). Revista Brasileira de Engenharia de Pesca 2017;10(1):58-68.

Kubtiza F. Coletânea de informações aplicadas ao cultivo do tambaqui, do pacu e de outros peixes redondos. Panorama da Aquicultura 2004; 14(82):27-39.

Lima LKF, Noleto SS, Santos VRV, Luiz DB, Kirschnik PG. Rendimento e composição centesimal do tambaqui (Colossoma macropomum) por diferentes cortes e categorias de peso. Revista Brasileira de Higiene e Sanidade Animal 2018;12(2):223 -235. 
Guimarães CC, Silva AJl, Cruz FGG, Rufino JPF, Silva AF, Costa VR

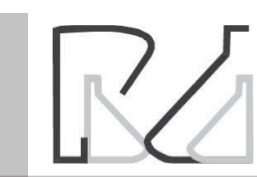

Maia Junior WM, Sales RO. Propriedades funcionais da obtenção da silagem ácida e biológica de resíduos de pescado. Revista Brasileira de Higiene e Sanidade Animal 2013;7(2):126-156.

Matterson LD, Potter LM, Stutz MW, Singsen EP. The metabolizable energy of feed ingredients for chickens [Research Report, 7]. Storrs: The University of Connecticut, Agricultural Experiment Station; 1965.

Nascimento MS, Freitas KFS, Silva MV. Produção e caracterização de silagens de resíduos de peixes comercializados no mercado público de Parnaíba-PI. Enciclopédia Biosfera 2014;10(18):2450-2458.

Oliveira CRC, Ludke MCMM, Ludke JV, Lopes EC, Pereira PS, Cunha GTG. Composição físico-química e valores energéticos de farinhas de silagem de peixe para frangos de corte. Arquivo Brasileiro de Medicina Veterinária e Zootecnia 2014;66(3):933-939.

Oliveira DD, Pinheiro JW, Fonseca NAN, Oba A. Desempenho de frangos de corte alimentados com torta de girassol. Ciências Agrárias 2012;33(5):1979-1990.

Rahman M, Koh K. Effects of formic acid-treated shrimp meal on growth performance and nutrient digestibility in broilers. Japan Poultry Science Association 2016;53(3):208-212

Ramírez JC, Ibarra JI, Romero FA, Ulloa PR, Ulloa JA, Matsumoto KS, et al. Preparation of biological fish silage and its effect on the performance and meat quality characteristics of quails (Coturnix coturnix japonica). Brazilian Archives of Biology and Technology 2013;56(6):1002-1010.

Ramírez-Ramírez JC, Huerta S, Arias L, Prado A, Shirai K. Utilization of fisheries by-catch and processing wastes for lactic acid fermented silage and evaluation of degree of protein hydrolysis and in vitro digestibility. Revista Mexicana de Ingeniería Química 2008;7(3):195-204.

Rodrigues PB, Martinez RS, Freitas RTF, Bertechini AG, Filho ET. Influência do tempo de coleta e metodologias sobre a digestibilidade e o valor energético de rações para aves. Brazilian Journal of Animal Science 2005;34(3):882-889
Digestibility and Physicochemical Characteristics of Tambaqui Waste Biological Silage Meal Included in Commercial Layer Diets

Rostagno HS, Albino LFT, Donzele JL, Gomes PC, Oliveira RF, Lopes DC, et al. Tabelas brasileiras para aves e suínos:composição de alimentos e exigências nutricionais. Viçosa: Universidade Federal de Viçosa; 2011.

Sakomura NK, Rostagno HS. Métodos de pesquisa em nutrição de monogástricos. Jaboticabal: Funep; 2007.

Sankar S, Sekar S, Mohan R, Rani S, Sundaraseelan J, Sastry TP. Preparation and partial characterization of collagen sheet from fish (Latescalcarifer) scales. International Journal of Biological Macromolecules 2008;42(1):69.

Sarruge JR, Haag HP. Análises químicas em plantas. Piracicaba: USP-Esalq; 1974.

Silva DJ, Queiroz AC. Análise de alimentos:métodos químicos e biológicos. $3^{\mathrm{a}}$ ed. Viçosa: UFV; 2012.

Silva MF. Elaboração e caracterização de silagem ácida de resíduos de tambaqui (Colossoma macropomum) [dissertation]. Manaus (AM): Universidade Federal do Amazonas; 2015.

Vidotti RM, Carneiro DJ, Macedo-Viegas EM. Acid and fermented silage characterization and determination of apparent digestibility coefficient of crude protein for pacu Piaracutus mesopotamicus. Journal of the World Aquaculture Society 2002;33:57-62.

Widjastuti TT, Lengkey HAAW, Wiradimadja R, Herianti D. Utilizing waste product of Tuna (Thunnusatlanticus) fish silage and its implementation on the meat protein conversion of broiler. Lucrări Ştiințifice, Seria Zootehnie 2011;55(16):83-87.

Yamamoto SM, Sobrinho AGS, Vidotti RM, Homem Junior AC, Pinheiro RSB, Buzzulini C. Desempenho e digestibilidade dos nutrientes em cordeiros alimentados com dietas contendo silagem de resíduos de peixe. Revista Brasileira de Zootecnia 2007;36(4):1131-1139. 